\title{
THIRD ANNUAL GENERAL MEETING
}

\section{MINUTES}

THE third Annual General Meeting of the Severn Wildfowl Trust was held at the Royal Society of Arts, 6 John Adam Street, Adelphi, London, W.C.2, on Friday, 17th March. The President, Field-Marshal Lord Alanbrooke was in the chair. The Minutes of the second Annual General Meeting having been circulated to Members in the printed Report were taken as read and signed by the President.

The adoption of the Report of the Council-necessarily a brief outline only of the Report which occupies the foregoing pages, together with the Balance Sheet and Accounts for 1949, was proposed by the President, seconded by the Director and carried unanimously.

The re-election of the following retiring Council Members was proposed by the President and seconded by the Treasurer, Sir Archibald Jamieson:

$$
\begin{aligned}
& \text { Capt. R. G. W. Berkeley. } \\
& \text { K. Miller Jones, Esq. }
\end{aligned}
$$

The motion was carried.

The re-election of the officers en bloc (as shown on p. 2) was proposed by Mr. Robert Aickman and seconded by Major Maxwell Knight.

The motion was carried.

The appointment of Messrs. S. J. Dudbridge \& Sons, of 8 Lansdown, Stroud, Gloucestershire, as Auditors for the ensuing year was proposed by the Director and seconded by Mr. Keith Miller Jones. The Director explained that the only reason for a change was a geographical one. The accountancy was now being done in Gloucestershire and it would be very much more convenient for the Auditors to be a local firm. It was explained that no other reason would have induced the Trust to discontinue its happy association with Messrs. W. B. Keen \& Co., who had always given such good service on such sympathetic terms. The meeting approved the Director's suggestion that a letter be sent to Messrs. Keen explaining the circumstances and thanking them for all they had done for the Trust in its formative years.

Major Douglas Cooper, R.E., drew the attention of the Council to the Severn Barrage Scheme which might possibly threaten the Trust. The Director indicated that our Vice-President, Mr. E. M. Nicholson, was keeping a watch on any such developments and would report to the Council if action seemed necessary.

Following the meeting, the President, Lord Alanbrooke showed his wonderful colour-films of the Trust. One reel was devoted to the wild geese and the second and third to shots, many of them superb close-ups, of the tame birds in the collection. Mr. Guy Benson proposed a vote of thanks to the President for giving the Members the opportunity of seeing such magnificent pictures.

Proceedings then terminated. 


\section{THE SEVERN WILDFOWL TRUST}

INCOME AND EXPENDITURE ACCOUNT FOR THE YEAR ENDED 31st DECEMBER, 1949

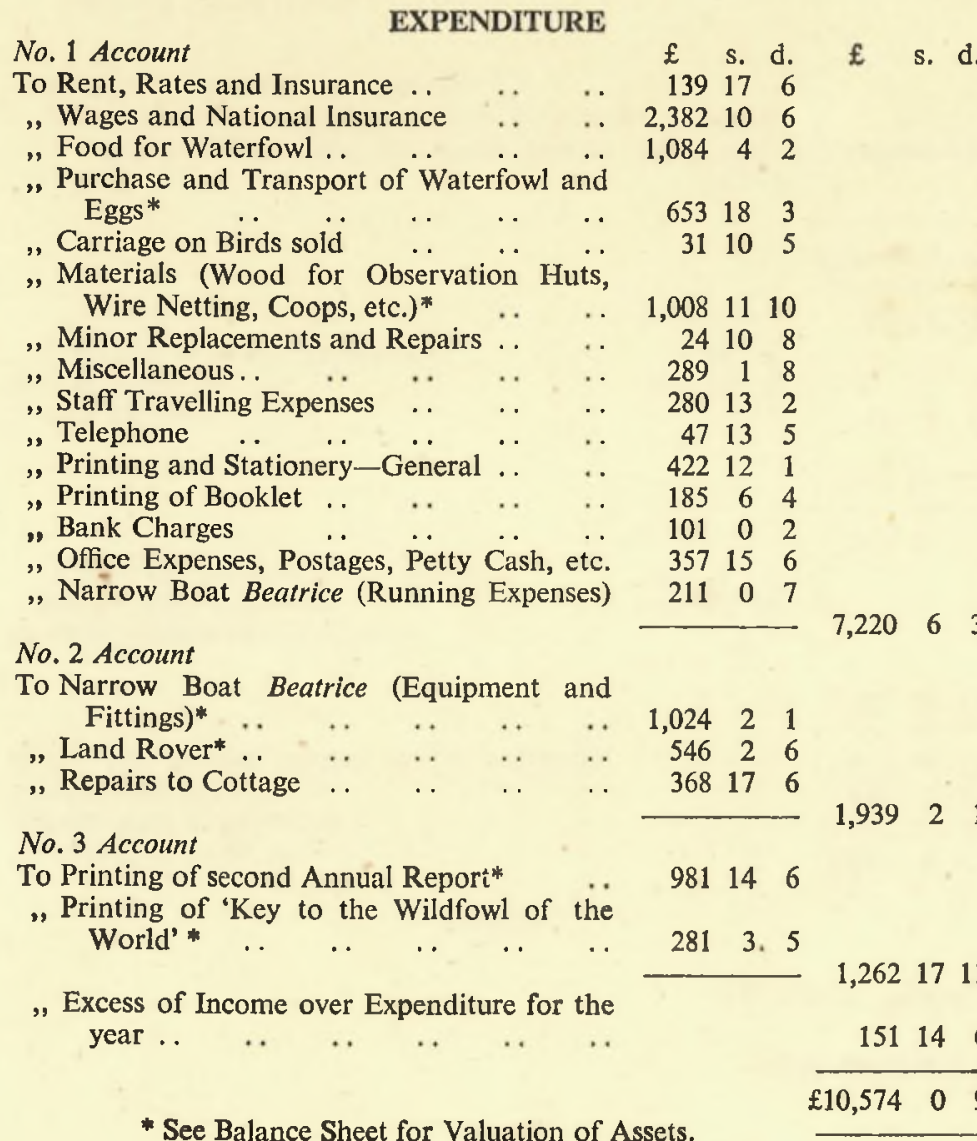
No. 1 Account$$
\text { Deeds of Covenant) }
$$
Income Tax recovered under Deeds Covenant
.. $\quad \cdots$
"Sale of first A
Sale of Booklet Report.
"Sale of Surplus Waterfowl ..
?
, Fees and Collections at Lectures
", Sale of Christmas Cards and Calendars .
, Narrow Boat Takings
, Gate Takings
"Freight Refunds and Sundry Sales.

No. 2 Account

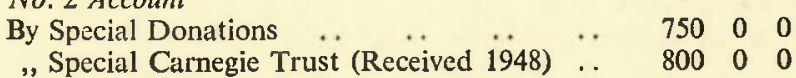

$3,358 \quad 2 \quad 5$

$\begin{array}{lll}401 & 5 & 1\end{array}$

$\begin{array}{lll}1,667 & 12 & 0\end{array}$

$\begin{array}{llll}403 & 12 & 0\end{array}$

$\begin{array}{lll}344 & 6 & 5\end{array}$

$1,097 \quad 15 \quad 1$

$\begin{array}{lll}603 & 2 & 1\end{array}$

$\begin{array}{lll}239 & 10 & 2\end{array}$

$136 \quad 14 \quad 2$

$\begin{array}{rrr}408 & 17 & 6 \\ 93 & 14 & 5\end{array}$

No. 3 Account

By Sale of second Annual Report $\quad \ldots \quad \ldots \quad 215 \quad 10 \quad 1$

"Sale of "Key to the Wildfowl of the World" $r \begin{array}{rrr}219 & 4\end{array}$

No. 3 Account 
BALANCE SHEET-31st DECEMBER, 1949

ASSETS

Waterfowl at Valuation.

Narrow Boat at Valuation

Land Rover, at Cost

Coops, Hen Houses, Scythes, etc., at Valuation

$$
\begin{array}{rrrrr} 
& & \multicolumn{1}{c}{£} & \text { s. } & \text { d. } \\
\ldots & \ldots & 4,986 & 0 & 0 \\
\cdots & \ldots & 1,000 & 0 & 0 \\
\ldots & \ldots & 546 & 0 & 0 \\
\cdots & \ldots & 671 & 0 & 0 \\
\cline { 3 - 5 } & & 7,203 & 0 & 0
\end{array}
$$

\section{Stock of Publications, at Cost-}

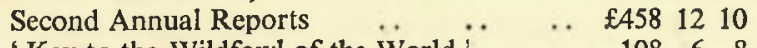

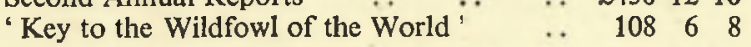

$$
\begin{array}{rr}
56619 & 6 \\
\hline 7,769196
\end{array}
$$

$\begin{array}{lll}67 & 4 & 7\end{array}$

Sundry Debtors

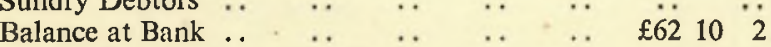

Less Cash in Hand-Overdrawn

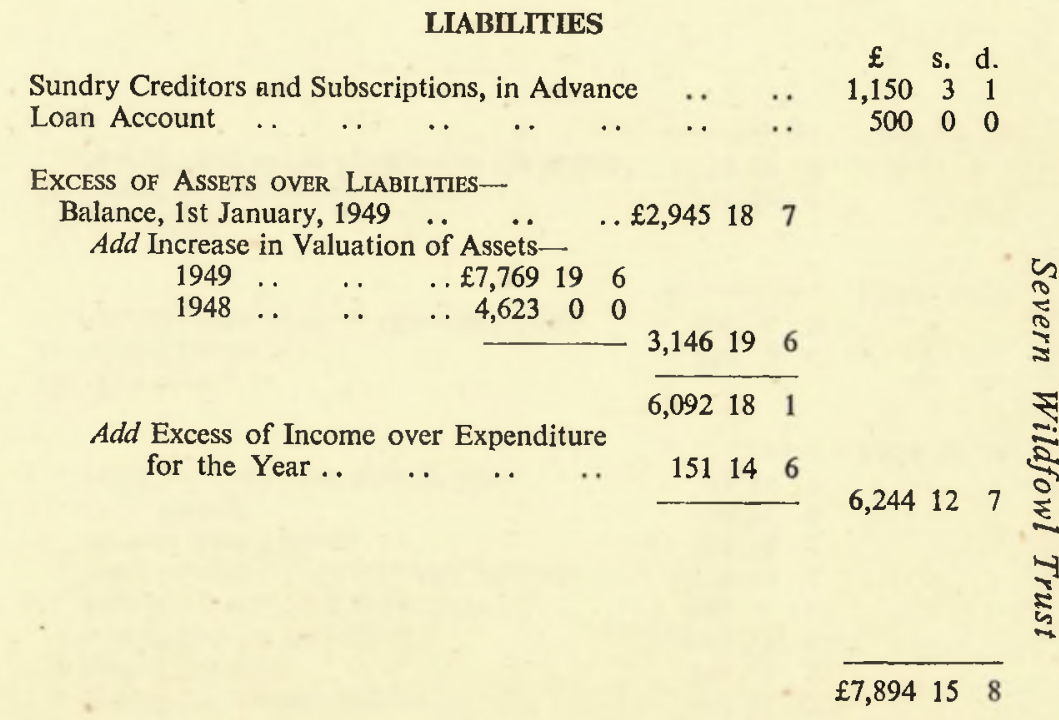

We have examined the above Balance Sheet and the accompanying Income and Expenditure Account with the Books, Vouchers and Accounts of the Trust and certify them to be in accordance therewith.

We have verified the Bank balance.

Finsbury Circus House,

Blomfield Street, London, E.C.2.

23rd February, 1950.
(Signed) W. B. KEEN \& CO.,

Chartered Accountants. 


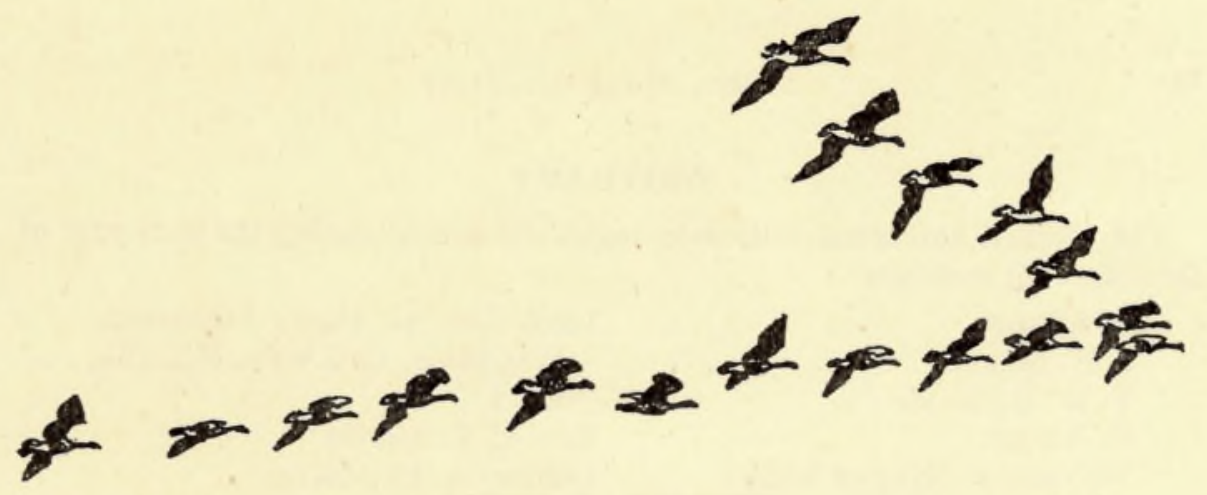

\section{ANNUAL DINNER}

After the Annual General Meeting, Members repaired to the Charing Cross Hotel where a Dinner was held. One hundred and twenty Members and guests assembled. The following were present:

R. F. Aickman, Mrs. R. F. Aickman, Field-Marshal Lord Alanbrooke, D. W. Allen and guest, Miss L. A. Auerbach and guest, H. G. Balfour, Mrs. E. Bate, Miss S. K. Bayley and guest, Guy Benson, Lady Violet Benson, J. Benson, N. Benson, Mrs. N. Benson, John Bevan, J. K. Blundell, Mrs. Boyd-Watt, C. Braby, Michael Bratby, Mrs. M. Bratby, F. E. Briscoe, Miss B. Briscoe, Hon. Alastair Buchan, M. Budger, Mrs. M. Budger, J. W. A. Calver, Miss V. Cameron, Hon. Martin Charteris, J. C. Christopherson and guest, Edwin Cohen, Mrs. E. Cohen, C. L. Coles, Miss S. Sinclair Davidson and guest, J. C. Davis and two guests, Miss D. H. de Beer, C. de Worms, H. J. Edmunds, F. A. Edmunds, K. V. Elphinstone, R. S. R. Fitter, Miss E. Forster, Mrs. J. Foljambe and guest, L. C. M. Gibbs and guest, F. Grant, Mrs. F. Grant, E. M. Heimann, Mrs. E. M. Heimann, Colonel W. F. Henn, P. W. Hinde, E. Horsfall, Major Gordon Hudson, Mrs. Gordon Hudson, Capt. Collingwood Ingram, M. J. Ingram, Sir Archibald Jamieson, K. Miller Jones, James Robertson Justice, Mrs. J. R. Justice, G. Kay and guest, Lord Kennet, Mrs. Rait Kerr, P. G. King, Major M. Knight, Mrs. M. Knight, Miss E. Koch, Mrs. D. Larcombe, C. Vaughan Lee, Mrs. C. Vaughan Lee, H. Lorand and guest, Colin McClean, Mrs. Marshall and guest, M. Mason, Miss V. Maxse, Miss D. Vaughan Morgan, J. C. A. Murray, Hugh Newman, Mrs. H. Newman, E. M. Nicholson, Miss E. Overend, T. L. Outhwaite, Lord Geoffrey Percy, G. L. Pilkington, Mrs. D. Pollock, R. Pugh, Mrs. R. Pugh, Sir Malcolm Sargent, Peter Scott, K. Shackleton, Mrs. Sladen and three guests, F. Evan Spicer and two guests, Mrs. L. Spinks, Miss Spinks, Miss M. Stretton and guest, Miss P. Talbot-Ponsonby, Miss P. Townsend and guest, Mrs. Turnbull, Mrs. P. V. Upton, Major-General C. B. Wainwright, G. T. Wilkins, Mrs. G. T. Wilkins, J. D. Wilson and guest.

The Toast List was as follows:

H.M. The King.

Proposed by the President, Field-Marshal the Rt. Hon. the Viscount Alanbrooke, K.G., G.C.B., O.M., D.S.O.

The Severn Wildfowl Trust.

Proposed by James Robertson Justice, Esq.

Reply by the Director, Peter Scott, Esq., M.B.E., D.S.C.

The Guests.

Proposed by the Rt. Hon. the Lord Kennet of the Dene, G.B.E., D.S.O., D.S.C.

Reply by the Guest of Honour, Sir Malcolm Sargent. 


\section{OBITUARY}

The Council has noted with deep regret the deaths during the past year of the following members:
P. Allison
J. H. Beacall
V. W. Bulstrode
Lieut.-Col. Sir Henry McMahon,
R. Burges
Viscountess Byng of Vimy
R. Caldicott
Colonel S. R. Clarke
A. C. D. Davidson
L. F. Farrell
Dr. D. F. Finlay
Sir Hugh Gladstone
Sir Mark Grant-Sturgis, K.C.B.
A. E. Ham
Miss A. A. King G.C.M.G., G.C.V.O., K.C.I.E., C.S.I.
Rev. C. E. Martin
Colonel A. D. Murray
S. K. Nichols
H. Playne
Mrs. J. Rankin
Miss P. Robinson
Miss G. M. Scott
J. Shipp
Mrs. C. E. Talbot-Ponsonby
F. B. Welch
Arthur Whitaker
A. F. L. Wilkinson

Mr. Rodney Dryland, Acting chief test pilot of the Glo'ster Aircraft Co., was killed while testing a Meteor at Moreton Valence Aerodrome in 1949. At the express wish of his family, Mr. Dryland's ashes were scattered from the air over the New Grounds by two of his colleagues, Squadron-Leader J. Zurakowski and Squadron-Leader J. Cooksey.

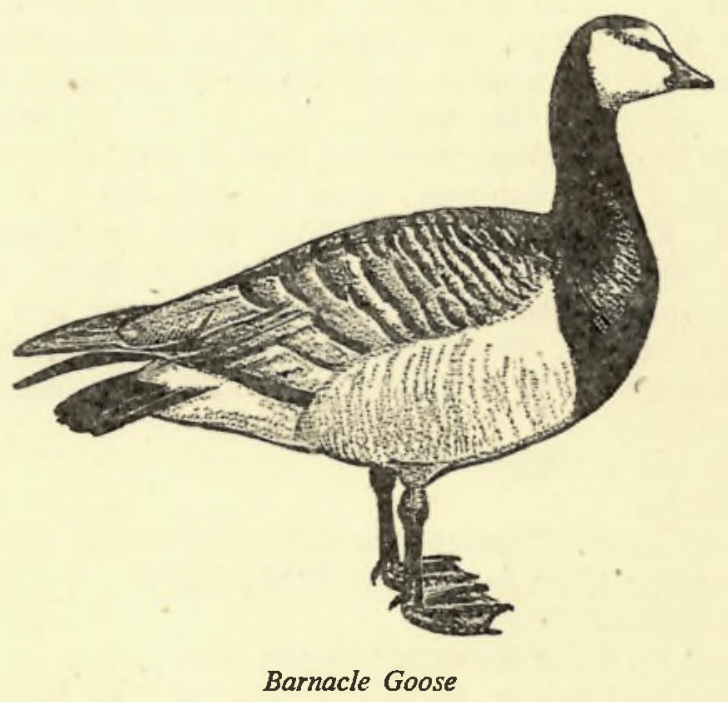

